\title{
Article \\ Dissimilar Welding of Low Alloy Steels Welded Joints: Effect of Run-Off and Run-On Plates
}

\author{
Park Jeongung ${ }^{1}$ (D) and Gyubaek An ${ }^{2, *(D)}$ \\ 1 Department of Civil Engineering, Chosun University, Gwangju 61452, Korea; jupark@chosun.ac.kr \\ 2 Department of Naval Architecture and Ocean Engineering, Chosun University, Gwangju 61452, Korea \\ * Correspondence: gyubaekan@Chosun.ac.kr; Tel.: +82-62-230-7210
}

Citation: Jeongung, P.; An, G. Dissimilar Welding of Low Alloy Steels Welded Joints: Effect of Run-Off and Run-On Plates. Metals 2021, 11, 642. https://doi.org/ $10.3390 /$ met11040642

Academic Editor: Byeong Choon Goo

Received: 25 March 2021

Accepted: 12 April 2021

Published: 14 April 2021

Publisher's Note: MDPI stays neutral with regard to jurisdictional claims in published maps and institutional affiliations.

Copyright: (c) 2021 by the authors. Licensee MDPI, Basel, Switzerland. This article is an open access article distributed under the terms and conditions of the Creative Commons Attribution (CC BY) license (https:// creativecommons.org/licenses/by/ $4.0 /)$.

\begin{abstract}
The steel run-off plates attached at the start and end of a weld usually have the same material, shape, and groove as the base metal according to the rules for designing and constructing ship steel structures. However, rather than using the same grade of base steel, readily available steel is often used for these plates to increase material utilization. When using dissimilar grade steel as a run-off plate, the physical properties of the base metal may be diluted if the weld joint of the base plate is penetrated, thereby lowering the physical property value of the joint. If the physical properties of the welded part of the real structure are lowered because of the dilution of the properties of the dissimilar grade steel material, the safety of the entire structure can be affected. Therefore, in this study, analyses of the metal microstructure, hardness, impact, and chemical composition were performed on surfaces where the run-off plate was removed after welding to examine the effect of dissimilar run-off plate. The results of this study reveal that the properties of the run-off plate were not diluted toward the base metal and the Charpy impact value at the weld end was up to $48 \%$ greater than the impact value at the start of the weld at a temperature of $-40{ }^{\circ} \mathrm{C}$.
\end{abstract}

Keywords: run-off plate; butt welding; metal microstructure; dissimilar welding; component analysis; dilution

\section{Introduction}

Run-off plates are temporarily attached to steel structures for a variety of purposes. For example, they are attached to the weld-line extension of the base material during welding operations (e.g., butt welding, head welding of flanges and webs, and edge welding) [1]. Generally, the run-off plate has the same material, shape, and groove properties as the base metal. Run-off plates are used to stably generate arcs at the beginning and end of the welding process. Without a run-off plate, defects including blowholes and craters are more likely [1]. The run-off plates help prevent defects from propagating to the base material. The welding is completed by extending the end of the weld by approximately $100 \mathrm{~mm}$ from the joint on the run-off plate, and the length of the extended weld becomes indispensable as the thickness of the steel plate increases. After welding is completed, the run-off plate is removed using gas cutting, and the cutting surface is treated by grinding. The run-off plate is generally manufactured from a weldable material, such as that of the base metal itself.

Another purpose of the run-off plate is to prevent end cracks during welding when the welding speed and heat input are high. Run-off plates are used to prevent gaps in the grooves from being opened or closed via thermomechanical deformation during rotary friction welding in one-sided butt welding [2,3], which depends on the amount of heat transferred and the welding speed. In particular, grooves tend to widen at high welding temperatures and speeds. This phenomenon largely occurs at the end of the weld, causing cracks to appear in the run-off plate attached to the end section. Moreover, this crack propagates to the base material after the run-off plate is removed, resulting in cold cracking. To prevent cold cracking [4-6], proper end fittings and special run-off plates must be 
installed. Therefore, securing the properties of the run-off plate is very important to ensure the safety of the structure.

A run-off plate attached at the start/end of welding is a steel plate that usually has the same material, shape, and groove as the base metal according to the rules for de-signing and constructing steel structures. However, rather than using the same grade of base steel as the run-off plate, readily available steel is often used to increase the material utilization rate [7-9]. When using dissimilar grade steel as a run-off plate, the problem arises that the physical properties of the run-off plate may be diluted if the weld portion of the base material is penetrated, thereby deteriorating the physical properties of the base weld portion. Accidents caused by weak structural integrity result in inflation in safety and cost concerns owing to the increasing design requirements [10]. Nouri [11] and Tomkow $[12,13]$ conducted a study on gas-metal arc welding and found that the faster the welding wire-feed rate, the greater the dilution, bead height, and width. The welding speed, in contrast, was reduced. Rogalski [14-17] et al. evaluated the integrity of the weld strength of dissimilar welds through macro-and microscopic examination and hardness measurements in TIG and laser welding. In heterogeneous laser welding of AISI 430F (X12CrMoS17) martensitic stainless steel and AISI 304 (X5CrNi18-10) austenitic stainless steel, a large number of pores were detected, and martensite increased compared to the base material in the heat affected zone, and a mixture was detected. The hardness range in the weld metal, caused by chemical inhomogeneity, was 184-416 HV0.3. Om and Pandey [18] and Gunaraja and Murugan [19,20] investigated the effects of submerged arc welding (SAW) polarity and weld parameters on the size and dilution of the heat-affected zone (HAZ). The investigation revealed that the width and area of the HAZ increased linearly with the heat input, irrespective of the polarity. To date, studies have been conducted on run-off plates to prevent cracking at the welding end and on the dilution between the base metal and welding wire during welding. However, practical research has not been conducted on the transfer of the properties of the run-off plate to the base material when welding is performed from the run-off plate to the base material. This study aims to solve the problem of satisfying the rule that the material of the run-off plate and the material of the base material must be the same material at steel structure manufacturing sites.

In this study, the effects of the material properties of the run-off plate on one of the bases after the removal of the Run-off plates were investigated. For this purpose, the effects of the components of the run-off plate on the base plate were evaluated by comparing and analyzing the metal microstructure, hardness, Charpy impact, and chemical composition of the surface upon removal of the run-off plate.

\section{Materials and Test Methods}

The material used in the experimental examination was AH36, DH36, EH36, a commercial, high-strength low-carbon steel that was fabricated by a thermo-mechanically controlled processing method (TMCP). Tables 1 and 2 present the chemical composition and the mechanical properties of the base metal and welding consumables, respectively, based on the specification requirements. Figure 1 shows the shape of the butt-welded specimen. The weld length was $200 \mathrm{~mm}$, the overall width was $300 \mathrm{~mm}$, and the thickness was $20 \mathrm{~mm}$. The run-off plate used here had dimensions of $100 \mathrm{~mm} \times 100 \mathrm{~mm} \times$ $20 \mathrm{~mm}$ (length $\times$ width $\times$ thickness). The welded joints were subjected to SAW with Y-grooves (Figure 1b), flux-core arc welding (FCAW), and multi-layer welding with Vgrooves (Figure 1c). Figure 2 shows a photograph of the SAW and FCAW specimens. Table 3 shows the butt-welded test specimen steel and welding methods used for the test, and Table 4 lists the welding conditions. Test specimen preparation and testing were performed according to ASTM standard A1106/A1106M-17. 
Table 1. Chemical compositions of specimen.

\begin{tabular}{|c|c|c|c|c|c|c|c|}
\hline & \multirow{2}{*}{ Specimen } & \multicolumn{6}{|c|}{ Chemical Composition (mass, \%) } \\
\hline & & $\mathrm{C}$ & Si & Mn & $\mathbf{P}$ & $S$ & $\mathrm{Ni}$ \\
\hline \multirow{4}{*}{ Base Metal } & MA-A(SS400) & 0.150 & 0.068 & - & 0.028 & 0.0144 & 0.0060 \\
\hline & AH32 & 0.129 & 0.044 & 0.1286 & 0.0145 & 0.0021 & 0.0001 \\
\hline & DH36 & 0.1551 & 0.441 & 0.1483 & 0.0170 & 0.0035 & 0.187 \\
\hline & EH36 & 0.156 & 0.045 & 0.1501 & 0.0154 & 0.0031 & 0.0020 \\
\hline \multirow{4}{*}{ Welding Consumables } & AWS A.5.17 F7A8 EH14 ( $\Phi 4.0$ mm) & & & & & & \\
\hline & for SAW & 0.120 & 0.020 & 2.02 & 0.0150 & 0.003 & - \\
\hline & (Hyundai Weld) & & & & & & \\
\hline & $\begin{array}{l}\text { AWS A5.29 E81T1-K2C }(\Phi 1.2 \mathrm{~mm}) \text { for } \\
\text { FCAW }(\mathrm{ESAB})\end{array}$ & 0.030 & 0.450 & 1.28 & 0.010 & 0.008 & 1.60 \\
\hline
\end{tabular}

Table 2. Mechanical properties and requirements of base metals and welding consumables.

\begin{tabular}{|c|c|c|c|c|c|c|c|}
\hline \multirow{3}{*}{\multicolumn{2}{|c|}{ Specimen }} & \multicolumn{6}{|c|}{ Mechanical Properties } \\
\hline & & \multirow{2}{*}{$\begin{array}{l}\text { Thickness } \\
\text { (mm) }\end{array}$} & \multirow{2}{*}{$\begin{array}{l}\text { Yield Stress } \\
\text { (MPa) }\end{array}$} & \multirow{2}{*}{$\begin{array}{c}\text { Tensile Strength } \\
\text { (MPa) }\end{array}$} & \multirow{2}{*}{$\begin{array}{l}\text { Elongation } \\
(\%)\end{array}$} & \multicolumn{2}{|c|}{$\begin{array}{l}\text { V-Type Impact Test (ABS) * } \\
\text { Mill Test Report }\end{array}$} \\
\hline & & & & & & Temp. $\left({ }^{\circ} \mathrm{C}\right)$ & $\mathbf{J}$ \\
\hline \multirow{4}{*}{$\begin{array}{c}\text { Base } \\
\text { Metals }\end{array}$} & MA-A(SS400) & 20 & 285 & 448 & 29 & - & - \\
\hline & AH32 & 20 & 379 & 515 & 28 & -40 & $\geq 27$ \\
\hline & DH36 & 20 & 394 & 552 & 30 & -40 & $\geq 27$ \\
\hline & EH36 & 20 & 415 & 576 & 28 & -40 & $\geq 27$ \\
\hline \multirow{6}{*}{$\begin{array}{c}\text { Welding } \\
\text { Consumables }\end{array}$} & AWS A.5.17 & & & & & & \\
\hline & F7A8 EH14 & - & & & & -20 & $\geq 27$ \\
\hline & $\begin{array}{l}(\Phi 4.0 \mathrm{~mm}) \\
\text { for SAW }\end{array}$ & - & 578 & 625 & 29 & $-62 *$ & $\geq 27 *$ \\
\hline & AWS A5.29 & \multirow{3}{*}{ - } & \multirow{3}{*}{526} & \multirow{3}{*}{602} & \multirow{3}{*}{29} & & \\
\hline & E81T1-K2C & & & & & -20 & $\geq 27$ \\
\hline & $\begin{array}{l}(\Phi 1.2 \mathrm{~mm}) \\
\text { for FCAW }\end{array}$ & & & & & $-40 *$ & $93 *$ \\
\hline
\end{tabular}

* Note: "ABS" refers to the American Bureau of Shipping standards.



(a)

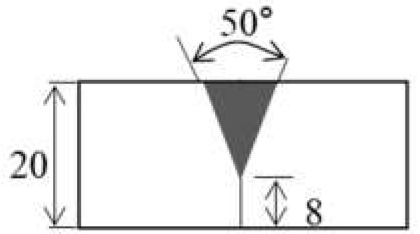

(b)

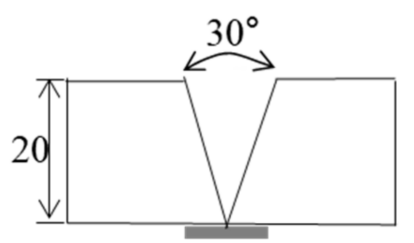

(c)

Figure 1. Dimension and groove shape: (a) dimension and configuration; (b) submerged arc welding (SAW) (B1, B2, B3, and B4); and (c) flux-core arc welding (FCAW) (B5). 


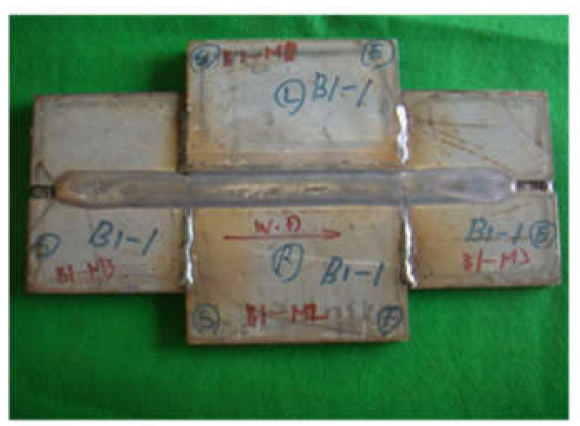

(a)

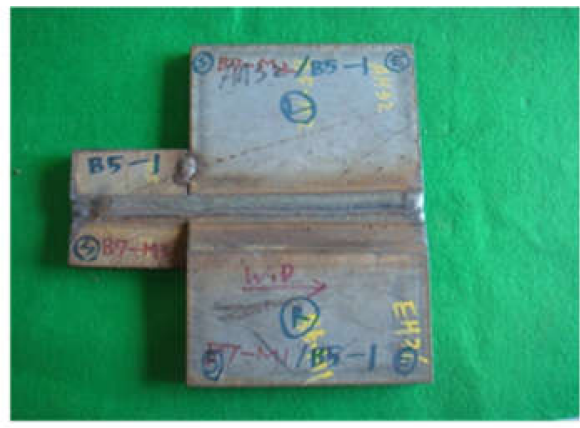

(b)

Figure 2. Welding specimens: (a) SAW (B1) and (b) FCAW (B5).

Table 3. Material and quantity.

\begin{tabular}{cccccc}
\hline Specimens & Base Metal 1 & Base Metal 2 & $\begin{array}{c}\text { Run-Off Plate } \\
\text { Metal }\end{array}$ & $\begin{array}{c}\text { Quantity } \\
\text { (Set) }\end{array}$ & Welding Procedure, Wire \\
\hline B1 & DH36 & AH32 & A (SS400) & 6 & - SAW \\
B2 & DH36 & DH36 & A (SS400) & 6 & -WIRE + FLUX: \\
B3 & EH36 & AH32 & A (SS400) & 6 & H-14 + SF-55ULT \\
B4 & EH36 & EH36 & A (SS400) & 6 & -FCAW \\
B5 & EH36 & AH32 & A (SS400) & 6 -WIRE: DS II-81-K2 \\
\hline
\end{tabular}

Table 4. Welding conditions.

\begin{tabular}{cccccc}
\hline \multicolumn{2}{c}{ Welded Joint } & Welding Current (A) & Arc Voltage (V) & Travel Speed (cm/s) & $\begin{array}{c}\text { Heat Input } \\
\text { (kJ/cm) }\end{array}$ \\
\hline \multirow{2}{*}{ B1-4 } & 1st (Face) & 850 & 32 & 32 & 51.0 \\
& 2nd (Root) & 920 & 35 & 40 & 48.3 \\
\hline \multirow{2}{*}{ B5 } & 1st Pass & 220 & 19 & 20 & 13.3 \\
& 2nd-5th Pass & 260 & 20 & 25 & 15.6 \\
\hline
\end{tabular}

Figure 3 shows the location of the test specimen at the beginning and end of the butt weld. To investigate the effect of dilution of the base metal and run-off plate, the latter was removed, and the test specimens were made from the beginning and the end of the weld.

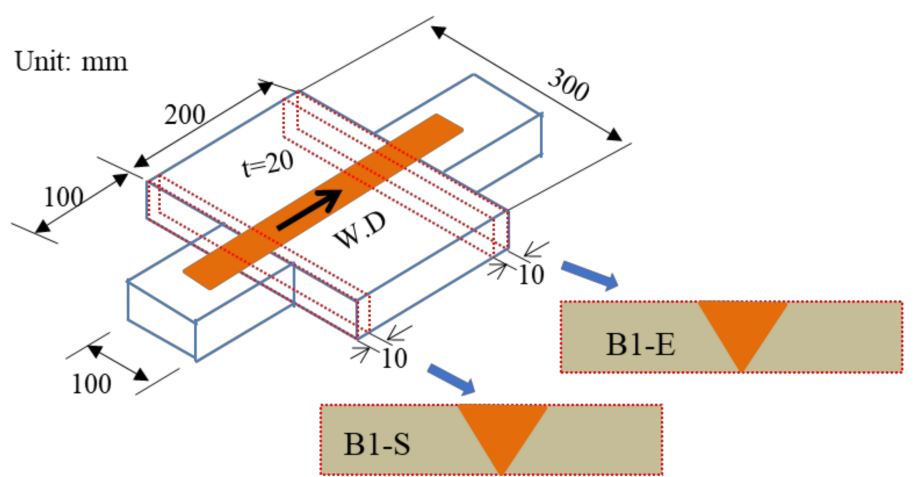

Figure 3. Location of specimen for hardness and dilution test.

At the beginning of the weld, much attention was paid to the possibility of bringing molten material from the run-off plate into the base metal, which could affect the properties of the base metal. B1-S denotes the test specimen, where B denotes the butt, the number 
denotes the test piece, $\mathrm{S}$ denotes the welding start portion, and $\mathrm{E}$ denotes the welding termination portion.

Figure 4 shows the location of the impact-test specimens taken from the root of the weld. For SAW, the specimens were taken from the beginning, end, and center of the weld, and the FCAW welds were taken from the beginning and center. The test temperatures were $-40{ }^{\circ} \mathrm{C}$ at the start and end of welding and $0,-20$, and $-40{ }^{\circ} \mathrm{C}$ at the center.



(a)

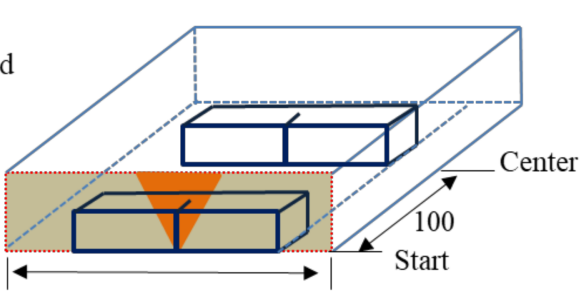

(b)

Figure 4. Position of specimens in impact test: (a) SAW (B1-B4) and (b) FCAW (B5).

\section{Results and Discussion}

\subsection{Microstructure and Hardness}

Mounting, polishing, and etching operations were required to inspect the metal microstructures of the base metal from where the run-off plates were removed. A resin and hardener were mixed and placed in a frame with a sample and subsequently hardened. The mounted specimens were then polished using rough and soft sandpapers consecutively. The surface of the test specimen was corroded using nitric acid and alcohol. The welds were cut, and the metal microstructure was observed under a $200 \times$ optical microscope (LEICA, model; Leica DM6000M, Micro Support Co., Ltd, Shizuoka, Japan). Figure 5 shows the metal microstructure at the face, center, and root of the cross-section after the removal of the run-off plate at the beginning and end of the weld about B1 and B5 on behalf of the specimens. The metal microstructures of the weld metal (WM), fusion line $(\mathrm{F} / \mathrm{L})$, fusion line and at $1 \mathrm{~mm}$ from the fusion line to width direction $(\mathrm{F} / \mathrm{L}+1)$, and fusion line and at $2 \mathrm{~mm}$ from the fusion line to width direction $(\mathrm{F} / \mathrm{L}+2)$ are also shown at their respective positions.

1: Acicular ferrite, 2: Grain boundary ferrite, 3: Ferrite side plate

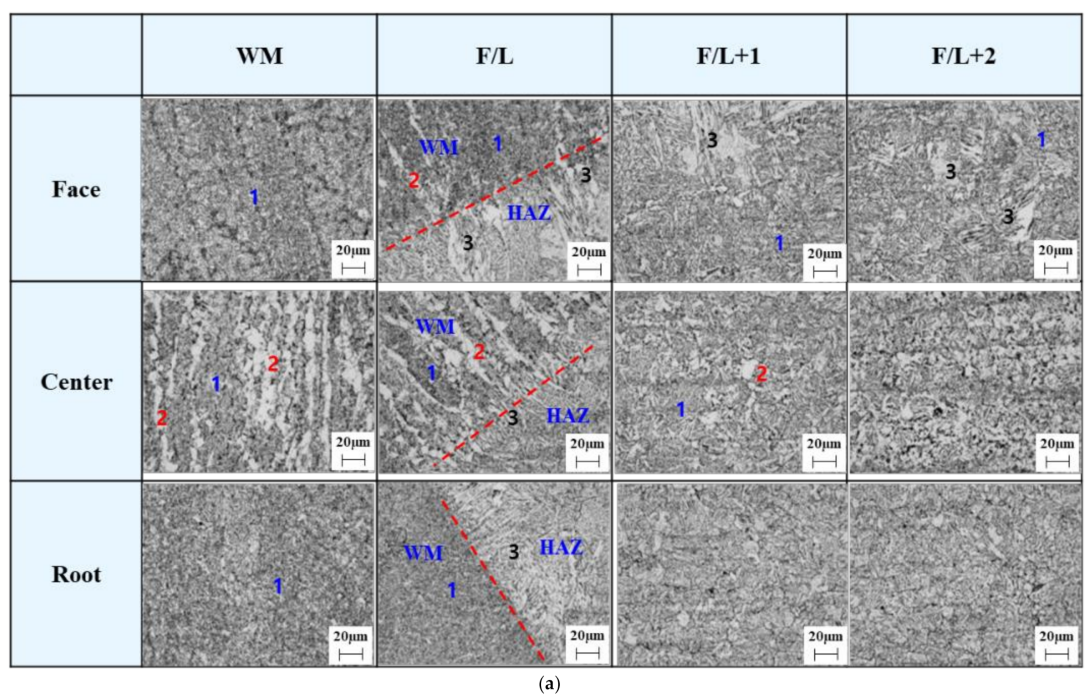

Figure 5. Cont. 


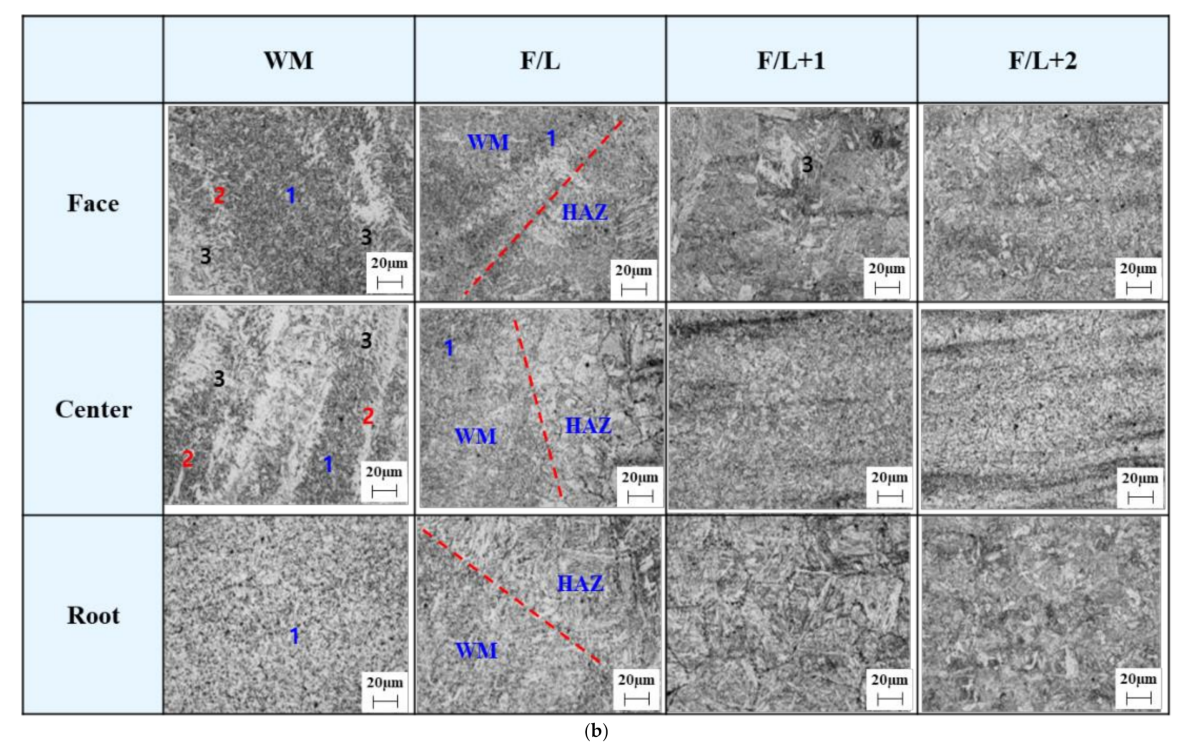

Figure 5. Microstructures of the weldment after removal of the run-off plate: (a) SAW (B1) and (b) FCAW (B5).

It can be seen that the microstructure of the deposited metal consists of grain-boundary ferrite (whitish) and acicular ferrite (black). A ferrite side plate (FSP) was developed in lath form along the grain-boundary ferrite. The mechanical properties of low-carbon welds are affected by the shape of the ferrite produced through the transformation during cooling, and the strength and toughness of the welds are related to the acicular ferrite fraction. The microstructure and fusion line are indicated by numbers and dotted lines in Figure 5. In the welded metal part of the SAW welding part, it can be seen that part of the reheating part of the face part, which is the first welding part, appeared by the second pass welding. To improve the toughness and strength, the grain-boundary ferrite and FSP transformation must be minimized, and needle ferrite should be produced in a larger fraction. It is evident from the micrographs that the microstructures of the test specimens were not significantly different.

The hardness values measured in the direction of the width from the center of the weld for the face, center, and root of the thickness are shown in Figure 6 (INDENTEC, model; ZH $\mu-\mathrm{A}$, Zwick Roell, Ulm, Germany). The measurement positions of the upper and lower surfaces were within $2 \mathrm{~mm}$ of the surface. Figure 7 shows the hardness values at the weld start and finish after the removal of the run-off plate. Adams reported that the cooling rate of a weld depends on the thickness and shape of the weld, welding conditions, temperature of the base metal, and preheat [21]. The weld metal and the HAZ of the SAW joints possess superior hardness to the base material, indicating the absence of a softening zone. Meanwhile, the hardness in HAZ of the FCAW is higher than that of the weld metal and base metal. This is because the SAW has a larger heat input than the FCAW, and its cooling rate is slow. Although the hardness value of the welded metal and the HAZ part is larger than that of the base metal, it is still less than $350 \mathrm{Hv10}$, which is the maximum value suggested by the American Bureau of Shipping (ABS) [22]. Therefore, it can be concluded that there was no change in the hardness value with respect to the run-off material. 




(a)

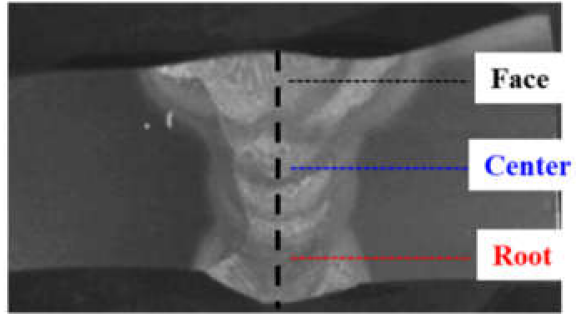

(b)

Figure 6. Position of specimens in hardness test: (a) SAW (B1) and (b) FCAW (B5).

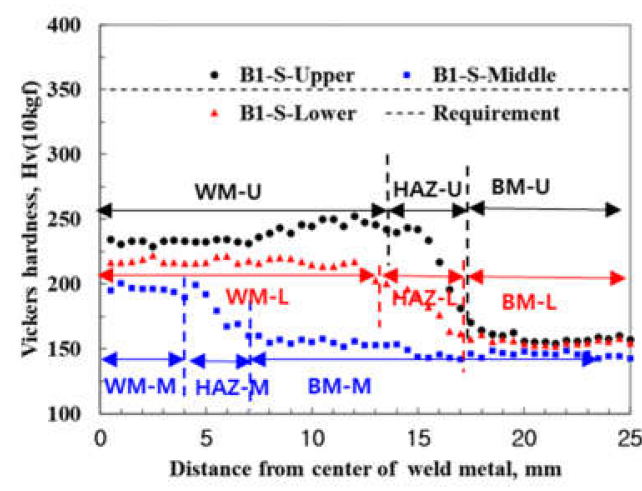

(a)



(c)

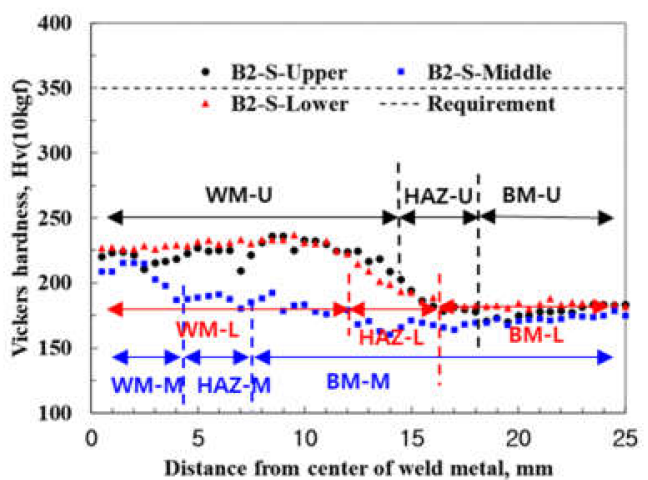

(b)

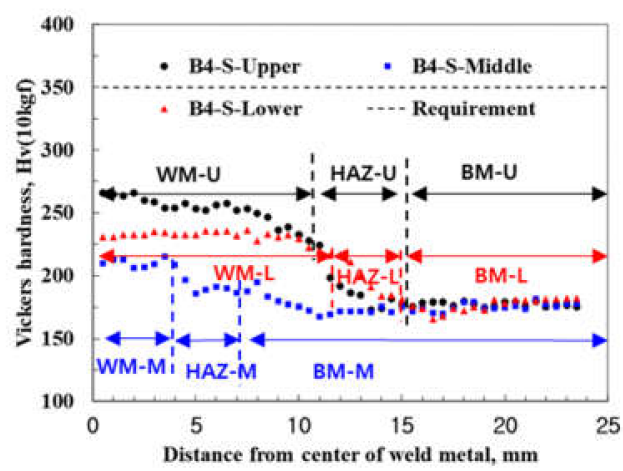

(d)

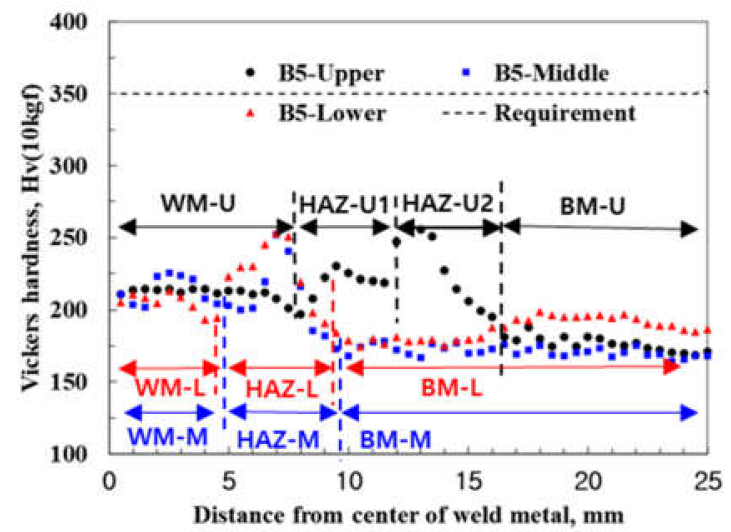

(e)

Figure 7. Hardness test (Hv10) for removal of the run-off plate in butt joint: specimens (a) B1; (b) B2; (c) B3; (d) B4; and (e) B5. 


\subsection{Toughness}

To confirm the toughness of the weld, Charpy impact tests were performed at $-40{ }^{\circ} \mathrm{C}$ at the start and end of the weld (Tinius Olsen, model: IT 406). The impact-test pieces were taken from the center of the welding length and subjected to an impact test at the experimental temperatures of $0,-20$, and $-40{ }^{\circ} \mathrm{C}$. The test results were averaged from three test pieces. Figure 8 shows a cross-sectional view of the specimen after the Charpy V-notch impact test.


Figure 8. Specimens of Charpy impact test at $-40{ }^{\circ} \mathrm{C}$.

Figure 9 shows the Charpy toughness at $-40{ }^{\circ} \mathrm{C}$ at the start, center, and end of welding. Test pieces B1-B4 are SA welds, and B5 comprises test pieces taken from the FCAW. All of the impact energy values shown are above $27 \mathrm{~J}$, which is the minimum value suggested by ABS [22]. According to the ABS standard, the welding part must satisfy the value of $27 \mathrm{~J}$ at $-20^{\circ} \mathrm{C}$. However, in this study, it can be seen that the more severe condition satisfies $27 \mathrm{~J}$ at $-40^{\circ} \mathrm{C}$. The Charpy impact value at the end of the weld was slightly larger than the start of the weld, but it was almost the same when considering the deviation of the experiment. In addition, both of the FCAW and SAW joints showed the satisfied rule requirement. According to the mill test report in Table 4, the SAW wire is a high-quality welding wire that can satisfy at least $27 \mathrm{~J}$ at $-60^{\circ} \mathrm{C}[23,24]$. Figure 10 shows the toughness of the experiment at $0,-20$, and $-40{ }^{\circ} \mathrm{C}$ for the center of the weld length. In this case, however, all of the results indicated that the value was above the required minimum value $(27 \mathrm{~J})$. Therefore, it can be concluded that even if the steel type of the run-off plate differs from that of the base metal, the material properties of the run-off plate do not influence the physical properties of the welding joints of the base metal.

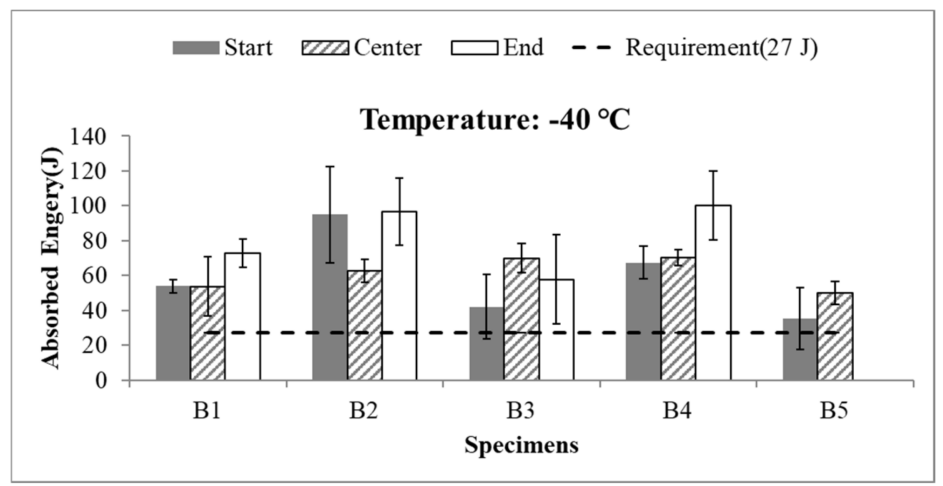

Figure 9. Results of Charpy impact test for start and end part of butt-welding joint. 


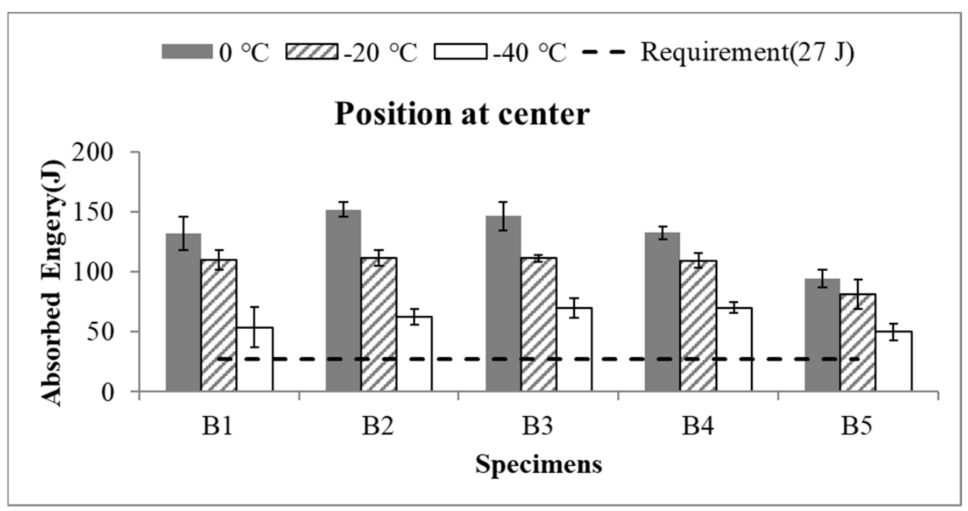

Figure 10. Results of Charpy impact test for welding center of butt-welding joint.

\subsection{Component Analysis}

A light-emission analysis and an emission spectrochemical analysis were performed to examine whether the metal component of the run-off plate was moved to the base material and diluted. The emission spectrochemical analysis (OXFORD, model: Foundry Master Xpert) is a method of quantitatively analyzing the spectral intensity of light emitted from a sample and determining the type or amount of the component element of the sample, based on the emission spectrum of the standard sample irradiated previously. Figure 11 shows the positions of the component analysis on the surface from which the run-off plate was removed. The measurement positions were located on the upper and lower welds (WM1 and WM2) and the two base metals (BM1 and BM2). In the graph, the components of the weld and base metals at the start/end of the weld are shown for comparison and analyzed.

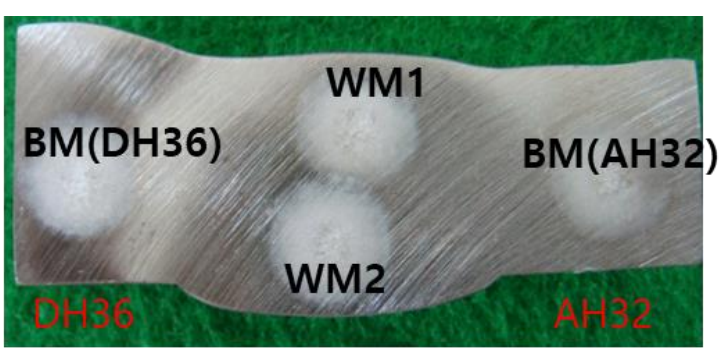

Figure 11. Position of dilution test for welding joint (B1).

Figure 12 shows a comparison of the welding metal component (WM1), base metal component (BM), run-off plate component (run-off plate), and welding wire component (wire) for the five test specimens. The B1-4 were fabricated via SAW. WM and BM are the measured values, and "run-off plate" and "wire" are the values of the mill test report. It is the Mn chemical content that differs significantly from the run-off plate and other metals in SAW. The Mn content of the run-off plate was $\sim 0.7 \%$, and approximately $1.2-2.0 \%$ in the weld wire and the measured base material. It can be seen that the chemical content of Mn between the run-off plate and the measured welding wire differs by approximately a factor of two. This indicates that the components of the run-off plate are not diluted by being transferred to the weld portion of the base material. By contrast, test piece B5 was fabricated via FCAW. Unlike SAW, the welding wire for FCAW contains $1.5 \%$ of Ni. Furthermore, $\sim 1.4 \%$ of $\mathrm{Mn}$ and $1.5 \%$ of $\mathrm{Ni}$ were detected in the wire, and $0.6 \%$ of $\mathrm{Mn}$ and $0.3 \%$ of $\mathrm{Cr}$ were detected in the run-off plate. Therefore, it can be confirmed that even with FCAW, the chemical composition of the run-off plate was not diluted by the weld of the base material. As in the result of this study and in the study of the effect of dilution of the welding part of the base material and lifting structure of different materials studied by Park [25] et al., the effect of the welding wire was the greatest on the welding part. 



(a)
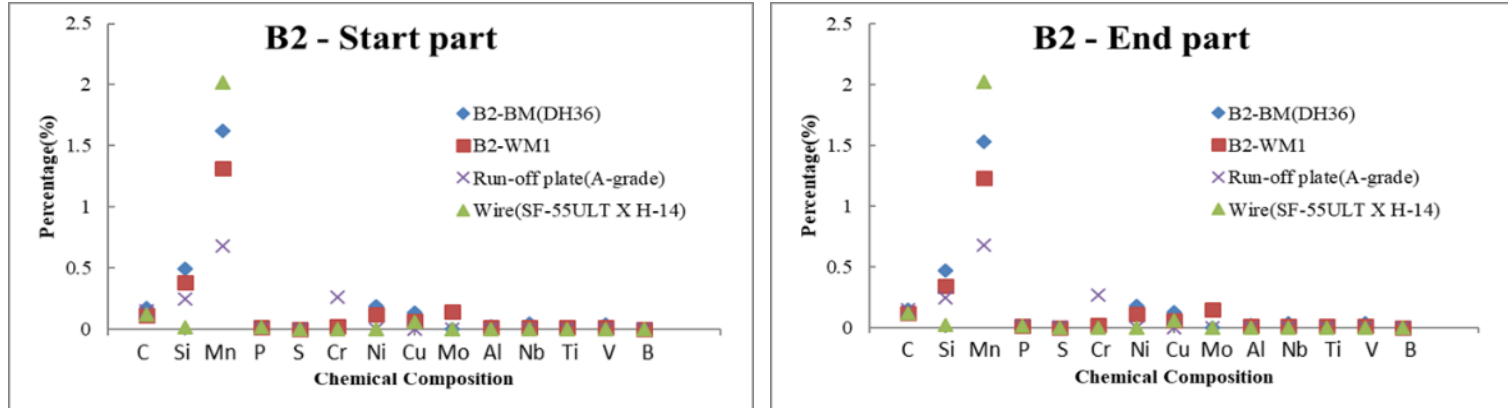

(b)


(c)


(d)

Figure 12. Cont. 




(e)

Figure 12. Results of chemical composition analysis of the weld joint for the removal of the run-off plate: (a) specimen B1-S and E; (b) specimen B2-S and E; (c) specimen B3-S and E; (d) specimen B4-S and E; and (e) specimen B5-S.

\section{Conclusions}

To investigate the effect of the material properties of the steel used in the run-off plate on the physical properties of the base metal after the run-off plates were removed, the microstructure, hardness test, Charpy impact test, and chemical compositions of the welding metal were compared and evaluated. In conclusion, the results of this analysis reveal that the properties of the run-off plate were not diluted toward the base metal, but only the properties of the welding wire were detected. A more detailed conclusion is as follows.

1. The metal microstructure of the cut surface was observed after the removal of the run-off plate. Only the metal microstructure of the welding wire could be observed in the weld metal, and changes in the metal microstructure caused by dissimilar welding between the base plate and run-off plate were not observed.

2. Although the hardness value of the welded part was larger than that of the other parts, it was still less than $350 \mathrm{Hv} 10$.

3. The Charpy impact value at the end of the weld was slightly larger than the start of the weld, but it was almost the same when considering the deviation of the experiment. And it was confirmed that all of the impact results obtained were at a reference value of $27 \mathrm{~J}$ or higher.

4. All of the components measured at the welded part coincided with the wire component. This demonstrates that components of the run-off metal are not transferred to the base metal during welding.

Author Contributions: Conceptualization and investigation, G.A.; writing-original draft preparation and writing-review and editing, P.J. All authors have read and agreed to the published version of the manuscript.

Funding: This study was supported by a research fund from Chosun University, 2019.

Institutional Review Board Statement: Not applicable.

Informed Consent Statement: Not applicable.

Data Availability Statement: The data presented in this study are available in the article.

Conflicts of Interest: The authors declare no conflict of interest.

\section{References}

1. Chen, W.-F.; Duan, L. Bridge Engineering Handbook: Construction and Maintenance; CRC Press: Boca Raton, FL, USA, 2014.

2. Satoh, K.; Mukai, Y.; Toyoda, M. Welding Engineering; Tokyo Rikogakusha Publishing Japan: Tokyo, Japan, 1979.

3. Masubuchi, K. Analysis of Welded Structures; Pergammon Press: Oxford, UK, 1980; pp. 268-269. 
4. Okuda, N.; Tanaka, K. Mechanism and Prevention of the End Crack in One Side Submerged Arc Welding (Report 1): The Effect of Welding Conditions and the Occurrence Mechanism. Trans. Jpn. Weld. Soc. 1983, 14, 63-64.

5. Okuda, N.; Tanaka, K. Mechanism and Prevention of the End Crack in One Side Submerged Arc Welding (Report 2): Observation of Rotative Distortion and Its Prevention with the Tab Plate. Trans. Jpn. Weld. Soc. 1983, 14, 66.

6. Asai, S. Trends of Automatic Welding System and In-Process Quality Control System. J. Jpn. Weld. Soc. 2012, 81, 34-44. [CrossRef]

7. Coniglio, N.; Cross, C.E.; Michael, T.; Lammers, M. Defining a critical weld dilution to avoid solidification cracking in aluminum. Weld. J. 2008, 87, 237s-247s.

8. Park, H.-C.; Lee, C.-H.; Chang, K.-H. Strengthening a damaged steel girder bridge by the replacement repair welding. KSCE J. Civ. Eng. 2012, 16, 1243-1249. [CrossRef]

9. Shin, H.S.; Park, K.T.; Lee, C.H.; Chang, K.H.; Van Do, V.N. Low temperature impact toughness of structural steel welds with different welding processes. KSCE J. Civ. Eng. 2015, 19, 1431-1437. [CrossRef]

10. Lee, J.-S.; Kim, M.-S. Strength Assessment of T-type Lifting Lugs Considering Deformation of Blocks. J. Ocean Eng. Technol. 2015, 29, 309-316. [CrossRef]

11. Nouri, M.; Abdollah-Zadeh, A.; Malek, F. Effect of welding parameters on dilution and weld bead geometry in cladding. J. Mater. Sci. Technol. 2007, 23, 817.

12. Tomków, J.; Fydrych, D.; Rogalski, G. Role of Bead Sequence in Underwater Welding. Materials 2019, 12, 3372. [CrossRef]

13. Tomków, J.; Janeczek, A.; Rogalski, G.; Wolski, A. Underwater Local Cavity Welding of S460N Steel. Materials 2020, $13,5535$. [CrossRef]

14. Rogalski, G.; Świerczyńska, A.; Landowski, M.; Fydrych, D. Mechanical and Microstructural Characterization of TIG Welded Dissimilar Joints between 304L Austenitic Stainless Steel and Incoloy 800HT Nickel Alloy. Metals 2020, 10, 559. [CrossRef]

15. Pańcikiewicz, K.; Świerczyńska, A.; Hućko, P.; Tumidajewicz, M. Laser Dissimilar Welding of AISI 430F and AISI 304 Stainless Steels. Materials 2020, 13, 4540. [CrossRef]

16. Landowski, M.; Świerczyńska, A.; Rogalski, G.; Fydrych, D. Autogenous Fiber Laser Welding of 316L Austenitic and 2304 Lean Duplex Stainless Steels. Materials 2020, 13, 2930. [CrossRef]

17. Świerczyńska, A.; Landowski, M. Plasticity of Bead-on-Plate Welds Made with the Use of Stored Flux-Cored Wires for Offshore Applications. Materials 2020, 13, 3888. [CrossRef] [PubMed]

18. Om, H.; Pandey, S. Effect of heat input on dilution and heat affected zone in submerged arc welding process. Sadhana 2013, 38, 1369-1391. [CrossRef]

19. Gunaraj, V.; Murugan, N. Prediction and comparison of the area of the heat-affected zone for the bead-on-plate and bead-on-joint in submerged arc welding of pipes. J. Mater. Process. Technol. 1999, 95, 246-261. [CrossRef]

20. Adams, C.M., Jr. Cooling Rates and Peak Temperatures in Fusion Welding. Weld. J. 1958, 37, $210-215$.

21. Sun, Y.L.; Obasi, G.; Hamelin, C.J.; Vasileiou, A.N.; Flint, T.E.; Balakrishnan, J.; Smith, M.C.; Francis, J.A. Effects of dilution on alloy content and microstructure in multi-pass steel welds. J. Mater. Process. Technol. 2018, 265, 71-86. [CrossRef]

22. American Bureau of Shipping. PART 2 Materials and Welding. In Regulations of the Classification and Registry of Ships; American Bureau of Shipping: Houston, TX, USA, 2019.

23. Bird, J. Improving the toughness of high strength GMA welds. Mar. Struct. 1993, 6, 461-474. [CrossRef]

24. Choi, D.; Lee, H.; Cho, S.-K.; Kim, H.C.; Hyun, S.-K.; Shin, S.Y. Microstructure and Charpy Impact Properties of FCAW and SAW Heat Affected Zones of $100 \mathrm{~mm}$ Thick Steel Plate for Offshore Platforms. Met. Mater. Int. 2020, 26, 867-881. [CrossRef]

25. Park, J.; An, G.; Lee, H. Influence on Properties of Base Metal after Elimination of Lifting-Lug Member in a Dissimilar Welding between Steel Base and Steel Lifting Lug. Int. J. Nav. Archit. Ocean Eng. 2019, 11, 858-864. [CrossRef] 